\title{
THE EFFECT OF POST-HARVEST TREATMENT AND STORAGE CONDITIONS ON VITAMIN C CONTENT IN TWO LEAFY PARSLEY CULTIVARS
}

\begin{abstract}
Monika SITAREK-ANDRZEJCZYK, Department of Vegetable and Medicinal Plants, Faculty of Horticulture,Biotechnology and Landscape Architecture, Warsaw University of Life Sciences - SGGW 159 Nowoursynowska Str., 02-776 Warsaw, Poland. monika sitarek@sggw.pl

Jarosław PRZYBYL, Department of Vegetable and Medicinal Plants, Faculty of Horticulture,Biotechnology and Landscape Architecture, Warsaw University of Life Sciences - SGGW 159 Nowoursynowska Str., 02-776 Warsaw, Poland. jaroslaw_przybyl@sggw.pl

Marek GAJEWSKI, Department of Vegetable and Medicinal Plants, Faculty of Horticulture,Biotechnology and Landscape Architecture, Warsaw University of Life Sciences - SGGW 159 Nowoursynowska Str., 02-776 Warsaw, Poland. marek_gajewski@sggw.pl (corresponding author)
\end{abstract}

\begin{abstract}
The objective of the study was to determine the content of vitamin C (L-ascorbic acid) in two leafy parsley (Petroselinum crispum Mill. Fuss) cultivars subjected to different post-harvest treatments. Ascorbic acid (AA), due to its instability, is one of the indicators of leafy vegetable freshness and quality. High content of this compound in vegetables is desired because of its bioactive properties. The cultivars differ in morphology of usable parts: 'Rialto' has flat lamina and 'Petra' triple-curled lamina. The plant material was obtained in 2015 and 2016 from experimental field in Warsaw-Wilanów. The leaves were washed directly after harvest: a) in tap water or b) in tap water with ozone added. Two methods of postharvest storage were applied: A) at the cold store and B) under simulated retail conditions. In the case of cold store method (A), the plants were tied in tufts and stored at the temperature of $0{ }^{\circ} \mathrm{C}$ and $\mathrm{RH} 90 \%$ for 7 , 14, 28 days in two variants: 1) in containers, where leaves petioles were immersed in water, and 2) in special bulk modified atmosphere packaging (MAP), dedicated to fresh herbs (Stepac, Israel). In the case of storage under simulated retail conditions (B), the leaves were kept for 48 hours at $10{ }^{\circ} \mathrm{C}$, RH 30-40\% in two variants: 1) tufts wrapped in perforated PE film with petioles immersed in water, and 2) packed to retail MAPs, dedicated to leafy herbs (Stepac, Israel). Concentration of L-ascorbic acid in the leaves was determined spectrophotometrically, with the method based on reaction of Folin's phenol reagent in low $\mathrm{pH}$. Fresh and stored 'Rialto' leaves were characterised by a higher concentration of AA than 'Petra' leaves (110 and $44 \mathrm{mg} \mathrm{g}^{-1}$ f.w., respectively). Significant decrease of AA after ozone treatment was observed only for 'Rialto' directly after harvest. Storage length had significant influence on the content of AA in both cultivars. Decrease of AA content was observed during storage period. Average concentration of AA after 7 days of storage was 85 and $44 \mathrm{mg} \mathrm{g}^{-1}$ f.w. for 'Rialto' and 'Petra', respectively. After 28 days of storage the concentration was $54 \%$ lower for 'Rialto' and 36\% lower for 'Petra', compared to the initial content. Leaves after simulated retail conditions showed slightly lower AA content than those stored for 7 days in the cold room. Retail MAPs guaranteed significantly higher preservation of AA in both cultivars than wrapping in film with immersing in water. Washing in ozone-added water showed influence only on AA content in 'Rialto' leaves wrapped in film - they showed lower concentration of AA under simulated retail conditions. Our study showed that the content of AA in parsley leaves was cultivar dependent. Ozone treatment did not have negative effect on AA during the storage. Storage duration, rather than packaging methods, plays a key role in preservation of high content of AA. However, method of packaging is important under retail conditions, where temperature is higher and $\mathrm{RH}$ is much lower, than at a cold room.
\end{abstract}

Keywords: ascorbic acid, MAP, parsley, storage, ozone

\section{INTRODUCTION}

Many epidemiological studies prove that a high consumption of fresh herbs, vegetables and fruits protect against certain types of cancer and other important diseases. Leafy parsley (Petroselinum crispum (Mill.) Fuss) is aromatic herb, popular in the World. It originates from the Mediterranean regions of Europe and is used for garnishing and seasoning. The seed oil is used as a flavouring agent for meat and sausages. The parsley is also known in traditional medicine as an effective remedy against digestive disorders, nephritis, kidney trouble, high blood pressure, eye disorders. The effect relates to presence of biologically active compounds in the leaves in stems. Parsley is rich in secondary metabolites of a wide spectrum of biological activities, such as phenylpropanoid apiol, oleanolic acid, furanocoumarin isoimperatorin and oxypeucedanin. It is also rich in vitamin $\mathrm{C}$ (Lisiewska and Kmiecik, 1997; Sbai et al., 2016). Vitamin C, which is chemically L-ascorbic acid (AA) - 2,3-enediol-L-gulonic 
acid-g-lactone, is an essential, water-soluble vitamin. For nutritional purposes, vitamin $\mathrm{C}$ is the sum of ascorbic acid and dehydroascorbic acid (DHAA) ('total ascorbic acid'). The DHAA absorbed from the intestinal tract undergoes intracellular reduction (via NADPH- and glutathione-dependent reductases), rendering it biologically active (Bender, 2003; Wilson, 2005). Vitamin C is a cofactor in numerous physiological reactions in important biochemical processes in human body. These include post-translational hydroxylation of proline and lysine in collagen and other connective tissue proteins. The vitamin also plays role in collagen gene expression, synthesis of norepinephrine and adrenal hormones, activation of many peptide hormones, as well as synthesis of carnitine (Davies et al., 1991; Arrigoni and De Tullio, 2000; Johnston et al., 2007; Smirnoff, 1996). Besides these key functions, AA also acts as a cellular antioxidant. It facilitates intestinal absorption of iron and maintenance of plasma iron in a reduced form (Bender, 2003; Smirnoff, 1996). USDA 'National Nutrient Database for Standard Reference' (USDA, 2017) is one of official sources of dietary recommendations for vitamin C intake. The Recommended Daily Allowance (RDA) for vitamin $\mathrm{C}$ is $25 \mathrm{mg} /$ day for children $4-8$ years old, $75 \mathrm{mg} /$ day for adult females, and $90 \mathrm{mg} / \mathrm{day}$ for adult men (Levine et al., 1995). Higher intake showed some health benefits for humans (Christen et al., 2010; Hemila, 2011; Honarbakhsh and Schachter, 2009; Jacob and Sotoudeh, 2002; Levine et al., 2009; Li and Schellhorn, 2007; Willcox et al., 2008). The basic natural sources of vitamin $\mathrm{C}$ are vegetables and fruits, including green leafy vegetables, like parsley (Eitenmiller et al., 2008).

Leafy aromatic plants, including leafy parsley, are prone to fast quality deterioration process. It results in tissue and cell integrity disruption, with a concomitant increase in enzymatic, respiratory and microbiological activity and therefore reduces shelf-life. As the result of the processes degradation of important for human biologically active compounds is observed (Watada et al., 1996; O'Beirn et al., 1999; Santos et al., 2014). This effect might be minimised by the use of adequate temperature management and modified atmosphere packaging (MAP). This technological method is used in postharvest preservation of many fruits and vegetables. MAP involves either actively or passively controlling or modifying the atmosphere surrounding the product within a package made of various types of polymeric films (Farber et al., 2003). In the case of parsley, some studies showed that the leaves kept in atmosphere composition of $10 \% \mathrm{O}_{2}$ and $10 \% \mathrm{CO}_{2}$ showed less decrease in chlorophyll (Yamauchi and Watada, 1993). Also parsley flavour and aroma were retained better in perforated film packages than in sealed ones (Manzano et al., 1995; Rosa et al., 2007). For storage of perishable vegetables and herbs special packaging films for MAPs were introduced by several producers, eg. Xtend film produced by Stepac, Israel (www.stepac.com/xtend). This film is used for special MAPs dedicated to different plant species, for storage in bulk on in retail. Food industry is also seeking for effective methods to ensure the safer food products, effective against food spoilage and pathogenic bacteria, yet harmless to humans. Ozone is a gas of strong antimicrobial action, due to potential oxidizing capacity and is used to disinfect water for drinking purposes in Europe (GuzelSeydim et al., 2004). Ozone destroys micro-organisms (bacteria and fungi) by the oxidation of vital cellular components. It is important that at room temperature, ozone decomposes quickly to oxygen. There are some attempts to introduce ozone for postharvest treatment of several horticultural crops, like vegetables and fruits (Suslov, 2017). According to literature sources, ozone was added to water for washing of fresh produce with the concentrations varied from $0.1 \mathrm{ppm}$ to $10 \mathrm{ppm}$, in relation to plant species (Hodges, 2003; Alexandre et al., 2011). Selma et al. (2007) reported that washing of lettuce leaves in water with ozone added in concentration of $1.6 \mathrm{ppm}$ or $2.2 \mathrm{ppm}$ for 1 min resulted in significant reduction of Shigella sonnei bacteria on the leaves. Positive effect of ozone treatment on lettuce microbial safety was confirmed also in Kim et al. (1999) report.

The aim of the study was to determine changes in the content of vitamin C (L-ascorbic acid) in two cultivars of leafy parsley, differed in leaves morphology, subjected to various post-harvest treatments.

\section{MATERIAL AND METHODS}

The storage experiment was performed in two successive growing seasons (2015 and 2016). The cultivars used in the study were 'Rialto' and 'Petra' (Bejo Zaden, Poland). The cultivars differ in morphology of usable parts: 'Rialto' is the cultivar with flat lamina and 'Petra' - with triple-curled lamina. The plant material was obtained from experimental field of Warsaw University of Life Sciences, located in Warsaw-Wilanów. The leaves were washed directly after harvest in: a) tap water or b) in tap water with ozone $\left(\mathrm{O}_{3}\right)$ added in the concentration of $5 \mathrm{ppm}$.

Two methods of postharvest storage were applied: A) in the cold store and B) in simulated retail conditions.

In the case of cold storage method (A), the plants were tied in tufts and stored at the temperature of $0^{\circ} \mathrm{C}$ and $\mathrm{RH}$ $90 \%$ for 7, 14, 28 days in two variants: 1) in containers, where leaves petioles were immersed in water, and 2) in bulk Modified Atmosphere Packagings (MAPs), dedicated to fresh herbs (Xtend film, Stepac, Israel).

In the case of retail conditions storage (B), the leaves were kept for 48 hours at $10^{\circ} \mathrm{C}, \mathrm{RH} 30-40 \%$, with access of light, in two variants: 1) tufts wrapped in perforated PE film sleeve, with petioles immersed in water (traditional method of parsley storage in retail), and 2) packed to retail Modified Atmosphere Packagings (MAPs), dedicated to leafy herbs (Xtend film, Stepac, Israel).

Ozone was continuously generated by ozone generator, efficiency of $3 \mathrm{~g} \mathrm{O}_{3} \mathrm{~h}^{-1}$. In the generator, oxygen from the air passed through a corona discharge generator to produce ozone. Washing of the plant material in water with established ozone concentration was done for 1 minute in a container, capacity of $100 \mathrm{dm}^{3}$, connected with ozone generator.

Concentration of AA in the plant leaves was determined spectrophotometrically, with the method based on reaction of Folin's phenol reagent in low pH (according to Jagota and Dani, 1982). For the analyses, representative samples of the plant material from each combination were taken. The analyses were carried out in four replicates from each experimental 
combination, based on the means of the two years of the study. Data obtained were subjected to statistical analysis in Statistica $^{\mathrm{TM}}$ software, using two- or three-way ANOVA.

\section{RESULTS AND DISCUSSION}

Leafy parsley is described as a good source of bioactive, health-promoting compounds, including ascorbic acid (Eitenmiller et al., 2008, Sbai et al., 2016). Parsley cultivars used in the study differed in AA content directly after harvest and washing, using the two washing variants (Table 1). 'Rialto' was characterized by a higher AA content than 'Petra parsley (110 and $44 \mathrm{mg} \mathrm{g}^{-1}$ f.w., respectively). The AA content in the plants was generally high and the results obtained by us are comparable to data reported for leafy parsley by other authors (Lisiewska and Kmiecik, 1997). Fresh and stored 'Rialto' leaves were characterised by significantly higher concentration of AA than 'Petra' leaves. It was found for both washing methods. However, for 'Rialto' parsley, ozone treated material showed a lower AA content than the untreated one. The negative effect of ozone on AA content for 'Rialto' parsley can be explained by different morphology of its leaves compared to 'Petra', which are flat and therefore more prone to gas exchange. Ozone, as a strong oxidant (Suslov, 2017) can oxidize AA in plant cells and therefore can influence AA degradation in parsley tissue observed in our study. AA is found in cell walls, as well as in cytosol, chloroplasts, mitochondria and vacuoles of plant cells. It is particularly sensitive to fluctuation of $\mathrm{pH}$, temperature, water content in the tissue, oxygen and light. These conditions may stimulate enzymatic oxidation of ascorbic acid to dehydroascorbic acid (also considered as active as the vitamin C). The reaction is reversible, but the dehydroascorbic acid is further converted to compounds no longer having biological properties, such as 2,3-diketogulonic acid or L-threonic acid and oxalic acid (Green and Fry, 2004). According to Smirnoff (1996), ascorbate in the cell walls is the first line of plant defence against ozone. This activity may explain the decrease of AA concentration after ozone treatment observed for 'Rialto' leaves. The losses of AA in response to fumigation with ozone was reported also by Guri (1983) for Phaseolus vulgaris. However, since there is no information on the effect of washing method or treatment with ozone on chemical composition of leafy parsley, it is impossible to directly compare the results obtained by us with other literature data.

Table 1. Ascorbic acid content in parsley leaves of both cultivars directly after harvest and washing (mg $100 \mathrm{~g}^{-1}$ f.w.)

\begin{tabular}{|c|c|c|c|}
\hline \multirow{2}{*}{ Washing method } & \multicolumn{2}{|c|}{ Cultivar } & \multirow[t]{2}{*}{ Means for the treatments } \\
\hline & Rialto & Petra & \\
\hline $\mathrm{H}_{2} \mathrm{O}$ & $123.9 \mathrm{a}$ & $44.6 \mathrm{c}$ & $84.2 \mathrm{~A}$ \\
\hline $\mathrm{H}_{2} \mathrm{O}+\mathrm{O}_{3}$ & $96.2 \mathrm{~b}$ & $43.4 \mathrm{c}$ & $69.8 \mathrm{~B}$ \\
\hline & \multicolumn{2}{|c|}{ Means for cultivars } & \\
\hline & $110.0 \mathrm{~A}$ & $44.0 \mathrm{~B}$ & \\
\hline
\end{tabular}

Values and means for factors which differ according to Tukey's HSD test at $\mathrm{p}=0.05$ are marked with different letters.

Storage of parsley in the cold store conditions showed, in the case of 'Rialto' leaves, no significant influence of washing method on AA content (Table 2). Storage method (in container + water or in bulk MAPs) significantly influenced AA content in the leaves. The content was higher in the case of storage in MAPs. It was also evident that with prolonging storage period AA content decreased significantly. The tendency was characteristic for both washing methods and both storage methods. The highest AA content was found for ozone treated parsley, stored in the cold room for 7 days in container + water, and the lowest AA content for ozone treated parsley packed in bulk MAPs and stored for 28 days.

Table 2. Ascorbic acid content in 'Rialto' parsley leaves after storage in cold store conditions ( $\mathrm{mg}^{100 \mathrm{~g}^{-1} \text { f.w.) }}$

\begin{tabular}{|c|c|c|c|c|}
\hline \multirow{3}{*}{ Washing method } & \multicolumn{3}{|c|}{ Storage periods (days) } & \multirow{3}{*}{$\begin{array}{l}\text { Means for the } \\
\text { treatments }\end{array}$} \\
\hline & 7 & 14 & 28 & \\
\hline & \multicolumn{3}{|c|}{ Storage method } & \\
\hline & \multicolumn{3}{|c|}{ In container + water } & $71.8 \mathrm{~A}$ \\
\hline $\mathrm{H}_{2} \mathrm{O}$ & $81.1 \mathrm{~b}$ & $57.2 \mathrm{~d}$ & $65.4 \mathrm{c}$ & $67.9 \mathrm{a}$ \\
\hline \multirow[t]{2}{*}{$\mathrm{H}_{2} \mathrm{O}+\mathrm{O}_{3}$} & $108.2 \mathrm{a}$ & $70.3 \mathrm{c}$ & $48.8 \mathrm{e}$ & $75.8 \mathrm{a}$ \\
\hline & \multicolumn{3}{|c|}{ In Xtend bulk MAPs } & $63.1 \mathrm{~B}$ \\
\hline $\mathrm{H}_{2} \mathrm{O}$ & $71.1 \mathrm{c}$ & $68.8 \mathrm{c}$ & $48.7 \mathrm{e}$ & $62.9 \mathrm{a}$ \\
\hline \multirow[t]{3}{*}{$\mathrm{H}_{2} \mathrm{O}+\mathrm{O}_{3}$} & $81.0 \mathrm{~b}$ & $68.9 \mathrm{c}$ & $39.9 \mathrm{f}$ & $63.3 \mathrm{a}$ \\
\hline & \multicolumn{3}{|c|}{ Means for storage periods } & \\
\hline & $85.3 \mathrm{~A}$ & $66.3 \mathrm{~B}$ & $50.7 \mathrm{C}$ & \\
\hline
\end{tabular}

Means for factors which differ according to Tukey's HSD test at $\mathrm{p}=0.05$ are marked with different capital letters.

Values inside the table which differ according to Tukey's HSD test at $\mathrm{p}=0.05$ are marked with different small letters.

In the case of 'Petra' parsley leaves it can be seen, based on the means for the treatments, that the washing with ozone-added water did not affect AA content (Table 3). With prolonging storage period AA content in the leaves decreased. The highest AA content was determined for the leaves after 7-day storage and the lowest for the leaves stored for 28 days in bulk MAPs and washed in ozone-added water. Average concentration of AA after 7 days of storage was 85 $\mathrm{mg} \mathrm{g}^{-1}$ f.w. for 'Rialto' and $44 \mathrm{mg} \cdot \mathrm{g}^{-1}$ f.w. for 'Petra' leaves. After 28 days of storage the concentration was about $55 \%$ and $35 \%$ lower for 'Rialto' and 'Petra', respectively, in comparison to the freshly harvested leaves. The decrease of AA content during storage and influence of storage temperature on AA changes in plants was reported also by Lee and Kader 
(2000).

Table 3. Ascorbic acid content in 'Petra' parsley leaves after storage in cold store conditions (mg $100 \mathrm{~g}^{-1}$ f.w.)

\begin{tabular}{|c|c|c|c|c|}
\hline \multirow{3}{*}{ Washing method } & \multicolumn{3}{|c|}{ Storage periods (days) } & \multirow{3}{*}{$\begin{array}{l}\text { Means for the } \\
\text { treatments }\end{array}$} \\
\hline & 7 & 14 & 28 & \\
\hline & \multicolumn{3}{|c|}{ Storage method } & \\
\hline & \multicolumn{3}{|c|}{ In container + water } & $38.1 \mathrm{~A}$ \\
\hline $\mathrm{H}_{2} \mathrm{O}$ & $41.3 \mathrm{ab}$ & $37.5 \mathrm{bc}$ & $30.5 \mathrm{c}$ & $36.4 \mathrm{a}$ \\
\hline \multirow[t]{2}{*}{$\mathrm{H}_{2} \mathrm{O}+\mathrm{O}_{3}$} & $46.0 \mathrm{a}$ & $33.8 \mathrm{c}$ & $39.7 \mathrm{~b}$ & $39.8 \mathrm{a}$ \\
\hline & \multicolumn{3}{|c|}{ In Xtend bulk MAPs } & $32.6 \mathrm{~B}$ \\
\hline $\mathrm{H}_{2} \mathrm{O}$ & $45.1 \mathrm{a}$ & $29.1 \mathrm{c}$ & $25.9 \mathrm{~cd}$ & $33.4 \mathrm{a}$ \\
\hline \multirow[t]{3}{*}{$\mathrm{H}_{2} \mathrm{O}+\mathrm{O}_{3}$} & $43.6 \mathrm{a}$ & $35.0 \mathrm{bc}$ & $17.1 \mathrm{e}$ & $31.9 \mathrm{a}$ \\
\hline & \multicolumn{3}{|c|}{ Means for storage periods } & \\
\hline & $44.0 \mathrm{~A}$ & $33.8 \mathrm{~B}$ & $28.3 \mathrm{C}$ & \\
\hline
\end{tabular}

Means for factors which differ according to Tukey's HSD test at $\mathrm{p}=0.05$ are marked with different capital letters.

Values inside the table which differ according to Tukey's HSD test at $\mathrm{p}=0.05$ are marked with different small letters.

In the case of storage at simulated retail conditions $\left(10^{\circ} \mathrm{C}\right)$, parsley leaves showed slightly lower AA content than those stored for 7 days in the cold room $\left(0^{\circ} \mathrm{C}\right)$ (Table 4 and 5). Retail MAPs guaranteed significantly higher preservation of AA in leaves of both cultivars than wrapping in film sleeve and immersing in water. Washing in ozone-treated water showed influence on AA concentration in 'Rialto' parsley immersed in water only. Also Gil et al. (1999) observed that vitamin $\mathrm{C}$ was better preserved in MAP-stored spinach than in those stored in ambient atmosphere. Similarly, modified atmosphere packaging (MAP) of broccoli florets resulted in better maintenance of AA, compared to broccoli stored under ambient atmosphere (Barth and Zhuang, 1996).

Table 4. Ascorbic acid content in 'Rialto' parsley leaves after storage in simulated retail conditions ( ${\mathrm{mg} 100 \mathrm{~g}^{-1} \text { f.w.) }}^{\text {. }}$

\begin{tabular}{|c|c|c|c|}
\hline \multirow[b]{2}{*}{ Washing method } & \multicolumn{2}{|c|}{ Method of storage } & \multirow[t]{2}{*}{ Means for the treatments } \\
\hline & $\begin{array}{l}\text { In PE film sleeve, immersed in } \\
\text { water }\end{array}$ & In Xtend retail MAPs & \\
\hline $\mathrm{H}_{2} \mathrm{O}$ & $81.0 \mathrm{a}$ & $78.8 \mathrm{a}$ & $79.9 \mathrm{~A}$ \\
\hline \multirow[t]{3}{*}{$\mathrm{H}_{2} \mathrm{O}+\mathrm{O}_{3}$} & $63.6 \mathrm{~b}$ & $82.1 \mathrm{a}$ & $72.8 \mathrm{~B}$ \\
\hline & \multicolumn{2}{|c|}{ Means for storage methods } & \\
\hline & $72.3 \mathrm{~B}$ & $80.5 \mathrm{~A}$ & \\
\hline
\end{tabular}

Means for factors which differ according to Tukey's HSD test at $\mathrm{p}=0.05$ are marked with different capital letters.

Values inside the table which differ according to Tukey's HSD test at $\mathrm{p}=0.05$ are marked with different small letters.

Table 5. Ascorbic acid content in 'Petra' parsley leaves after storage in simulated retail conditions $\left(\mathrm{mg}^{100 \mathrm{~g}^{-1} \text { f.w.) }}\right.$

\begin{tabular}{|c|c|c|c|}
\hline \multirow[b]{2}{*}{ Washing method } & \multicolumn{2}{|c|}{ Method of storage } & \multirow{2}{*}{ Means for the treatments } \\
\hline & $\begin{array}{l}\text { In PE film sleeve, immersed in } \\
\text { water }\end{array}$ & In Xtend retail MAPs & \\
\hline $\mathrm{H}_{2} \mathrm{O}$ & $35.6 \mathrm{~b}$ & $46.2 \mathrm{a}$ & $40.9 \mathrm{~A}$ \\
\hline $\mathrm{H}_{2} \mathrm{O}+\mathrm{O}_{3}$ & $43.7 \mathrm{ab}$ & $41.9 \mathrm{ab}$ & $42.8 \mathrm{~A}$ \\
\hline \multicolumn{3}{|c|}{ Means for storage methods } & \\
\hline & $39.7 \mathrm{~B}$ & $44.1 \mathrm{~A}$ & \\
\hline
\end{tabular}

Means for factors which differ according to Tukey's HSD test at $\mathrm{p}=0.05$ are marked with different capital letters.

Values inside the table which differ according to Tukey's HSD test at $\mathrm{p}=0.05$ are marked with different small letters.

The experiment showed that washing of plant material in ozonated water did not have negative effect on further loss of AA content during storage of parsley in the cold store. However, it is worth noting that in the case of retail conditions 'Rialto' leaves previously washed in ozonated water and not stored in MAPs were characterized by a lower content of AA. Certainly, storage duration, not packaging methods tested in the study influenced the content of AA during prolonged storage. However, method of packaging is more important in retail, where storage temperature is higher then in a cold store and $\mathrm{RH}$ is much lower.

\section{CONCLUSION}

Washing in ozonated water does not significantly effect vitamin C content in stored leaves of 'Rialto' and 'Petra' parsley in the case of cold store and in simulated retail conditions, as well. However, ozone treatment decreased AA content in flat-lamina leaves of 'Rialto' when they were analyzed directly after the treatment, before storage. Flat-lamina ('Rialto) and curled-lamina ('Petra') leafy parsley retain high content of AA if stored at cold store conditions up to 7 days in tufts immersed in water and in bulk MAPs (with or without previous washing in ozone-added water). After 14 days of storage in cold store conditions the loss of ascorbic acid is higher for 'Petra' parsley than for 'Rialto'. Leafy parsley stored under retail conditions, which are characterized by a higher temperature and lower relative humidity then cold store conditions, keep more ascorbic acid when stored in dedicated retail MAPs, than when stored with traditional method in tufts immersed in water. Further studies on different ozone concentrations are suggested, to establish optimal 
concentration /treatment time combination for parsley.

\section{REFERENCES}

1. Alexandre, E.M.C., Santos-Pedro, D.M., Brandão, T.R.S, SilvaInfluence, C.L.M. 2011. Influence of aqueous ozone, blanching and combined treatments on microbial load of red bell peppers, strawberries and watercress. Journal of Food Engineering. Vol.105, Iss. 2, pp. 277-288. https://doi.org/10.1016/j.jfoodeng.2011.02.032

2. Arrigoni, O., De Tullio, M.C. 2000. The role of ascorbic acid in cell metabolism: between gene-directed functions and unpredictable chemical reactions. Journal of Plant Physiology. Vol. 157, pp. 781-788. https://doi.org/10.1016/S0176-1617(00)80102-9

3. Barth, M.M., Zhuang, H. 1996. Packaging design affects antioxidant vitamin retention and quality of broccoli florets during postharvest storage. Postharvest Biology and Technology. Vol.9, Iss. 2, pp. 141-150. https://doi.org/10.1016/S0925-5214(96)00043-9

4. Bender, D.A., 2003. Vitamin C (ascorbic acid). In: Bender, D.A. (Ed.), Nutritional Biochemistry of the Vitamins. 2 nd ed. Cambridge University Press, Cambridge, UK, pp. 357-384. https://doi.org/10.1017/CBO9780511615191.014

5. Christen, W.G., Glynn, R.J., Sesso, H.D., Kurth, T., MacFadyen, J., Bubes, V., Buring, J.E., Manson, J.E., Gaziano, J.M. 2010. Age-related cataract in a randomized trial ocvitamins E and C in men. Archives of Ophthalmology. Vol. 128, Iss. 11, pp. $1397-1405$. https://doi.org/10.1001/archophthalmol.2010.266

6. Davies, M.B., Austin, J., Partridge, D.A. 1991. Vitamin C: Its Chemistry and Biochemistry. Royal Society of Chemistry, Cambridge, UK.

7. Eitenmiller, R.R., Ye, L., Landen Jr., W.O. 2008. Ascorbic acid: vitamin C. In: Eitenmiller, R.R., Ye, L., Landen, Jr., W.O. (Eds.). Vitamin Analysis for the Health and Food Sciences. 2nd ed. CRC Press, Boca Raton, FL, USA, pp. 231-289.

8. Farber, J.N., Harris, L.J., Parish, M.E., Beuchat, L.R., Suslow, T.V., Gorny, J.R. 2003. Microbiological safety of controlled and modifed atmosphere packaging of fresh and fresh-cut produce. Comprehensive Reviews in Food Science and Food Safety. Vol. 2 , Iss. 1, (Supplement), pp. 142-160. https://doi.org/10.1111/j.1541-4337.2003.tb00032.x

9. Gil, M.I., Ferreres, F., Tomás-Barberán, F.A. 1999. Effect of Postharvest Storage and Processing on the Antioxidant Constituents (Flavonoids and Vitamin C) of Fresh-Cut Spinach. Journal of Agricultural and Food Chemistry. Vol. 47, Iss. 6, pp. $2213-2217$. https://doi.org/10.1021/jf9812001

10. Green, M.A., Fry, S.C. 2004. Vitamin C degradation in plant cells via enzymatic hydrolysis of 4-O-oxalyl-1-threonate. Nature. Vol. 433 (7021), pp. 83-87. https://doi.org/10.1038/nature03172

11. Guri, A. 1983. Variation in glutathione and ascorbic acid content among selected cultivars of Phaseolus vulgaris prior to and after exposure to ozone. Canadian Journal of Plant Science. Vol. 63, Iss. 3, pp. 733-737. https://doi.org/10.4141/cjps83-090

12. Guzel-Seydim, Z.B., Greeneb, A.K, Seydim, A.C. 2004. Use of ozone in the food industry. Food Science and Technology. Vol. 37 , Iss. 4, pp. 453-460. https://doi.org/10.1016/j.lwt.2003.10.014

13. Hemila, H. 2011. The effect of vitamin C on the common cold. Journal of Pharmacy Practice. Vol. 24, pp $241-242$. https://doi.org/10.1177/0897190010392376

14. Honarbakhsh, S., Schachter, M. 2009. Vitamins and cardiovascular disease. British Journal of Nutrition. Vol. 101, pp. 1113-1131. https://doi.org/10.1017/S000711450809123X

15. Hodges, D.M. 2003. Postharvest Oxidative Stress in Horticultural Crops. CRC Press, pp. 13-30

16. Jacob, R.A., Sotoudeh, G. 2002. Vitamin C function and status in chronic disease. Nutrition in Clinical Care. Vol. 5, Iss. 5, pp. 6674. https://doi.org/10.1046/j.1523-5408.2002.00005.x

17. Jagota, S.K., Dani, H.M. 1982. A new colorimetric technique for the estimation of vitamin C using Folin phenol reagent. Analytical Biochemistry. Vol. 127, Iss. 1, pp. 178-182. https://doi.org/10.1016/0003-2697(82)90162-2

18. Johnston, C.S., Steinberg, F.M., Rucker, R.B. 2007. Ascorbic acid. In: Zempleni, J., Rucker, R.B.,McCormick, D.B., Suttie, J.W. (Eds.), Handbook of Vitamins. 4th ed. CRC Press, Boca Raton, FL, USA, pp. 489-520.

19. Kim, J.G., Yousef, A.E., Grady, W.C. 1999. Use of ozone to inactivate microorganisms on lettuce. Journal of Food Safety. Vol. 19, Iss. 1, pp. 17-34. https://doi.org/10.1111/j.1745-4565.1999.tb00231.x

20. Lee, S.K., Kader, A.A. 2000. Preharvest and postharvest factors influencing vitamin C content of horticultural crops. Postharvest Biology and Technology. Vol. 20, Iss. 3, pp. 207-220. https://doi.org/10.1016/S0925-5214(00)00133-2

21. Levine, M., Dhariwal, K.R., Welch, R.W., Wang, Y., Park, J.B. 1995. Determination of optimal vitamin C requirements in humans. American Journal of Clinical Nutrition. Vol. 62, pp. 347-356.

22. Levine, M., Espey, M.G., Chen, Q. 2009. Losing and finding a way at C: new promise for pharmacologic ascorbate in cancer treatment. Free Radical Biology and Medicine. Vol. 47, pp. 27-29. https://doi.org/10.1016/j.freeradbiomed.2009.04.001

23. Li, Y., Schellhorn, H.E. 2007. New developments and novel therapeutic perspectives for vitamin C. Journal of Nutrition. Vol. 137 , pp. 2171-2184.

24. Lisiewska, Z., Kmiecik, W. 1997. Effect of freezing and storage on quality factors in Hamburg and leafy parsley. Food Chemistry. Vol. 60, Iss. 4, pp. 633-637. https://doi.org/10.1016/S0308-8146(97)00048-4

25. Manzano, M., Citterio, B., Maifreni, M., Paganessi, M., Comi, G. 1995. Microbial and sensory quality of vegetables for soup packaged in different atmospheres. Journal of Science and Food Agriculture. Vol. 67, pp. 521-529. https://doi.org/10.1002/jsfa.2740670415

26. O’Beirn, D., Francis, G.A., Thomas, C. 1999. The microbiological safety of minimally processed vegetables. International Journal of Food Science and Technology. Vol. 34, pp. 1-22. https://doi.org/10.1046/j.1365-2621.1999.00253.x

27. Rosa, C., Sapatab, M., Guerra, M.M. 2007. Chemical and sensory characteristics and microbiological safety of fresh finely chopped parsley packed in modifed atmosphere. Food Control. Vol. 18, pp. 1008-1012. https://doi.org/10.1016/j.foodcont.2006.06.006 
28. Santos, J., Herrero, M., Mendiola, J.A., Oliva-Teles, M.T., Ibanez, E., Delerue-Matos, C., Oliveira, M.B.P.P. 2014. Fresh-cut aromatic herbs: Nutritional quality stability during shelf-life. LWT - Food Science and Technology. Vol. 59, Iss. 1, pp. $101-107$. https://doi.org/10.1016/j.lwt.2014.05.019

29. Sbai, H., Saad, I., Ghezal, N., Greca, M.D., Haoual, R. 2016. Bioactive compounds isolated from Petroselinum crispum L. leaves using bioguided fractionation. Industrial Crops and Products. Vol. 89, pp. 207-214. https://doi.org/10.1016/j.indcrop.2016.05.020

30. Selma, V.M., Beltra, D., Allende, A., Chacon-Vera, E. Gila, M. 2007. Elimination by ozone of Shigella sonnei in shredded lettuce and water. Food Microbiology. Vol. 24, pp. 492-499. https://doi.org/10.1016/j.fm.2006.09.005

31. Smirnoff, N. 1996. Botanical Briefing: The Function and Metabolism of Ascorbic Acid in Plants. Annals of Botany. Vol. 78, Iss. 6 , pp. 661-669. https://doi.org/10.1006/anbo.1996.0175

32. Suslov, T.V. 2017. Ozone applications for postharvest disinfection of edible horticultural crops. Univ. of California, ANR Publ. 8133. http://ucdavis.edu. (Accessed: 10.08.2017).

33. USDA 2017. Nutrient Database for Standard Reference, Release 24. Retrieved September 10, 2017 from the Nutrient Data Laboratory Home Page: http://www.nal.usda.gov/fnic/foodcomp/search/.

34. Watada, A.E., Ko, N.P., Minott, D.A. 1996. Factors affecting quality of fresh-cut horticultural products. Postharvest Biology and Technology. Vol. 9, pp. 115-125. https://doi.org/10.1016/S0925-5214(96)00041-5

35. Willcox, B.J., Curb, J.D., Rodriguez, B.L. 2008. Antioxidants in cardiovascular health and disease: key lessons from epidemiologic studies. American Journal of Cardiology. Vol. 101, pp. 75-86. https://doi.org/10.1016/j.amjcard.2008.02.012

36. Wilson, J.X. 2005. Regulation of vitamin C transport. Annual Review of Nutrition. Vol. 25, pp. $105-125$. https://doi.org/10.1146/annurev.nutr.25.050304.092647

37. Yamauchi, N., Watada, A.E. 1993. Pigment changes in parsley leaves during storage in controlled or ethylene containing atmosphere. Journal of Food Science. Vol,.56, pp. 616-637. https://doi.org/10.1111/j.1365-2621.1993.tb04339.x 